\title{
Variations in the Golgi Complex of Mouse Prolactin Cells at Different Times in a Circadian Period ${ }^{1}$
}

A variation in the Golgi complex of somatotrops of mice killed at noon, 18.00 and midnight, during a 24-h period, was recently reported ${ }^{2}$.

CLARK and BAKER ${ }^{3}$ reported, in 1964, a circadian variation in the prolactin content of rat pituitary and, recently, MEIER ${ }^{4}$ has demonstrated circadian variations in the metabolic effect of prolactin.

Bearing in mind these facts we have checked the material used for the previous report, looking for timedependent changes in the Golgi complex of mouse prolactin cells. The material and methods used are the same as previously described ${ }^{2}$.

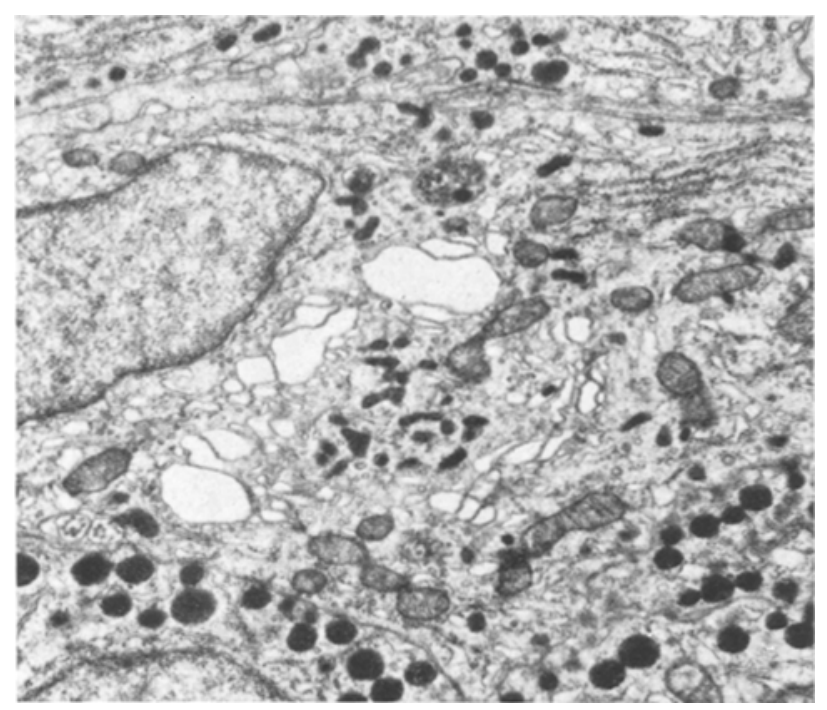

Fig. 1. Prolactin cell of an animal killed at noon. The Golgi complex is hypertrofied and immature granules can be seen inside the Golgi zone. $\times 10,000$.

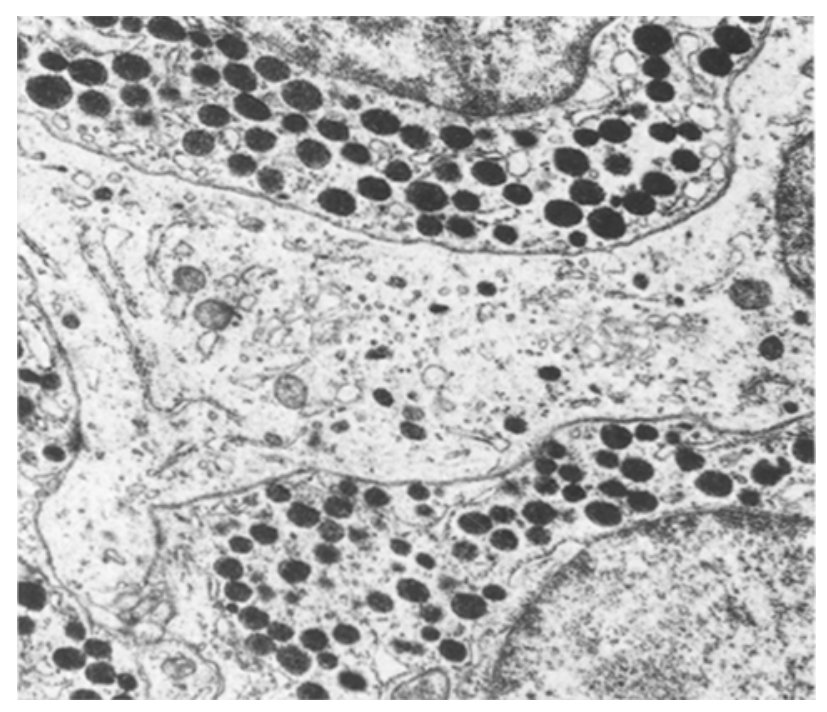

Fig. 2. Prolactin cell of an animal killed at midnight. The Golgi complex is very small although well defined. $\times 10,000$.
The prolactin cells are easily recognizable in the male mouse pars distalis. Their ultrastructural characteristics correspond to those reported by others in the mouse ${ }^{5,6}$, or in the rat 7,8 . They are medium sized, of a very irregular form, with projections of the cytoplasm insinuating between the other cell types and sometimes involving them, particularly the STH cells. Their nuclei appear round, oval or irregularly outlined. The cytoplasm contains a variable number of highly dense, specific granules. They are spherical, oval, rodshape or irregularly shaped, ranging from $250-400 \mathrm{~nm}$ in maximal diameter. The endoplasmic reticulum is rough surfaced and more abundant in the distal part of the cytoplasmic projections, particularly in those limitating with capillaries.

The Golgi complex of most prolactin cells, appears very well developed in the animals killed at noon (Figure 1), containing within the Golgi zone a variable quantity of immature granules. In contrast, the animals killed at midnight have prolactin cells in which Golgi complex is very well defined but not developed and no immature granules can be seen within the Golgi zone (Figure 2).

Our results fit quite well with the circadian variations in the prolactin content of rat hypophysis described by $\mathrm{Cl}_{\mathrm{ARK}}$ and BAKER ${ }^{3}$. These authors found a peak of concentration at 16.00 . Our own results, in which prolactin cells are forming granules actively at noon, made us to think that sometime later the mouse hypophysis might contain, as the rat hypophysis does, a maximal concentration of prolactin.

The description of circadian variations in ultrastructural aspects of the parenchymal cells of the pars distalis, will not only provide a more complete picture of these cell types but will also allow us to eliminate some contradictions existing in the literature.

Resumen. El aparato de Golgi de las células a prolactin de la pars distalis de la hipofisis del ratón, presenta un desarrollo variable en distintos momentos de un período circadiano. Está muy desarrollado y contiene numerosos gránulos en formación en animales sacrificados al mediodía, mientras que está muy poco desarrollado en los animales sacrificados a la medianoche.

\section{L. Gómez Dumm and J. M. Echave Llanos}

Instituto de Embriologia, Biologia e Histologia,

Facultad de Ciencias Médicas,

Universidad Nacional de La Plata,

La Plata (Argentina), 7 April 1970.

1 This investigation was supported with a grant from the Comision de Investigación Científica de la Universidad Nacional de la Plata. Thanks are due to the members of the technical s'aff of the Institute for their technical assistance.

2 C. L. Gómez Dumm and J. M. Echave Llanos, Experientia 26, $177(1970)$

3 R. H. Clark and B. L. BAker, Science 143, 375 (1964).

4 A. H. MEIER, Gen. comp. Endocr. 2, 55 (1969).

a. SANo, J. Cell. Biol. 75, 85 (1962).

6 B. G. Barnes, in Cytologie de l'adenohypophyse (Ed. P. Benort; CNRS, 1963), p. 91.

7 R. E. Smith and M. G. Farquhar, J. Cell. Biol. 31, 319 (1966). 8 J. L. Pasteels, in Cytologie de l'adenohypophyse (Ed. P. Benoit; CNRS, 1963), p. 137. 